\title{
The global economy affected by the COVID-19
}

\author{
Ladislav Vagner ${ }^{1, *}$ \\ ${ }^{1}$ University of Zilina, Faculty of Operation and Economics of Transport and Communications, \\ Univerzitna 1, 01026 Zilina, Slovakia
}

\begin{abstract}
Research background: The disease, which broke out in December 2019 in the Chinese city of Wuhan and caused a pandemic around the world, has a constant impact on the economies of the countries even after almost two years. The issue of the effect of COVID-19 on the global economy and overall earnings management persists. Due to the topicality of the problem, we focused on the impacts and measures affecting the company's operation. Purpose of the article: The purpose of this research article is to summarize current information on coronavirus and its effects almost two years after the outbreak. Additionally, outline three different scenarios that could occur. We also took into consideration scientific sources that deal with the shock of COVID-19. In addition, we summarize the opinions of scientific authors. Methods: Within the methodology, we used mainly the analysis and obtaining an objective picture of the current situation in the world. Following the outbreak of the pandemic, there have been significant inconstancies in GDP. Subsequently, we focus on the development of individual selected macro indicators that best describe the global economy. Findings \& Value added: Finally, we offer three scenarios that outline three different situations that may occur, which we worked on based on a scenario analysis based on a modification of the sensitivity analysis, to specify future development scenarios based on macroeconomic indicators.
\end{abstract}

Keywords: global economy; coronavirus; scenario analysis

JEL Classification: $F 01 ; O 11 ; C 82$

* Corresponding author: ladislav.vagner@,fpedas.uniza.sk 


\section{Introduction}

For today's globalized world, the COVID-19 pandemic is bringing an unprecedented test. It is a crisis that is reminiscent of the financial crisis of 2008 and has enormous consequences not only for the world economy but also for the daily lives of billions of people around the world. COVID-19 has claimed nearly 5 million lives, and many who are not directly affected by the disease have lost their jobs, have fallen into extreme poverty, or are experiencing longterm lockdown and a drastic change in their lives (Fialova and Vasenska, 2020; Korzeb and Niedziolka, 2020). To prevent the spreading of the COVID-19 pandemic, countries worldwide have taken various restrictive measures that have negatively affected the world economy and international trade in goods and services. The COVID-19 brings significant changes for both the economy and foreign trade. The current development of the epidemiological situation in the world has resulted in changes in globalization processes that affect the economies and policies of individual states as well as international business between them. Many authors point to the fact, that COVID-19 has created an atypical situation where highly infectious disease has affected all the world's major economies simultaneously. Countries, which are responsible for more than two-thirds of world production, are taking anti-epidemiological measures that would normally appear extreme. At the same time, they state that government measures to stabilize the number of new cases reduce economic activity. It follows that a recession is a necessary public health measure.

The extent of the global impact of a pandemic on individual economies is closely linked to how open the economy is to international trade (Acikgoz, O., \& Gunay, 2020). Using the ratio of exports to GDP as an indicator of export performance and sensitivity to foreign demand, they confirm that in more open economies there will be a more significant impact due to declining foreign demand.

Due to either voluntary social isolation or state-imposed lockdown, there is a reduction in the workforce in many economic sectors. This issue is addressed by several authors. In their scientific articles, they address changing consumer behaviour and the industries affected by the pandemic. According to the authors, for example, the automotive, freight, and electronics industries are deeply affected by measures to reduce the spread of the virus. Attendance and organization of public, sports, and cultural events have also been drastically reduced. Businesses providing specific services such as hairdressers, taxis, or gyms are also at risk. Tourism and tourism businesses are also experiencing a significant decline in sales as people's mobility in the world has fallen sharply.

\subsection{Theoretical background}

According to the authors Ozili and Arun (2020), these are two methods by which the coronavirus suppressed economic activities. On the one hand, the spread of the virus has encouraged social distance, which has led to the closure of financial markets, corporate offices, businesses, and stocks. And also, the exponential rate at which the virus spreads. Uncertainty about the extent to which the situation may worsen has led to the security of consumption and investment among consumers, investors, and international trading partners. His findings show that the growing number of days of lockouts, monetary policy decisions, and restrictions on international travel have seriously affected the level of economic activity and the closing, opening, lowest, and highest stock prices of major stock market indices.

The negative effect of the pandemic was addressed by Khan et al. (2021). Apart from the adverse consequences on health care and the social sphere, it has not forgotten the economy. He addressed the impact of the slowdown in production, the slowdown in sales growth, losses in international trade, and supply chain problems. COVID-19 has affected sources of supply and is affecting the global economy. Travel from one country to another is limited due to the 
increase in cases following international visits. COVID-19 has restricted movement between countries, and various solutions to the crisis have emerged using IoT sensors and algorithms (Lyons and Lazaroiu, 2020). A similar issue was addressed by Scott et al. (2020).

UNCTAD, the United Nations Trade and Development Agency, has already warned against reducing global growth to below $2 \%$ in 2020 , which could ultimately wipe out $\$ 1$ trillion in the total value of the global economy (Bagchi et al., 2020). The vulnerability of world economies has increased as growth has slowed, and the expansion of various countries is now less able to absorb shocks. Given the exogenous shock that hit the world economy, the recession was the most likely scenario (Carlsson-Szlezak, 2020).

Due to the measures associated with COVID-19, not to mention the closure of establishments due to the occurrence of positive cases of the disease, it may be reduced on the supply side and, conversely, consumers will reduce their costs. They will postpone their purchases due to uncertain times, shifting the demand curves inward. These results in a fall in GDP, an increase in unemployment, and a moderation in price increases. Part of the lost demand will be restored after the epidemic subsides (Lambovska et al., 2021). However, part of demand will be permanently lost, reducing long-term global economic growth. Inflation has occurred in stock prices, with stock markets rising as investors borrow money at almost zero interest rates (Maital and Barzani, 2020).

The impact of COVID-19 will be uneven in terms of space and time. It is, therefore, necessary for each country, tourism sector, and sub-sector to have tailored measures and focus on entrepreneurship according to the current norm. Many authors argue that businesses and countries that will prosper after COVID-19 will be those that show customer and employee care, plan to compete in the new world, and maintain and optimize liquidity during and after COVID-19. By the time it is necessary to use idea management to find ways for system applicable not just locally but globally also (Mikelsone et al., 2020).

The outbreak of the COVID-19 pandemic in any country currently poses an incalculable risk to global health and the global economy (Alam and Abdurraheem, 2021).

According to authors Saunders-Hastings and Krewski (2016), there have been several pandemics over the last hundred years. These pandemics include the "Great Plague" (Reichmund, 2021), Justinian Plague (Wagner et al., 2014), Black Death (Horrox, 2013), the Third Plague Pandemic (Bratu, 2020, Tan et al., 2002), Spanish influenza (Gibbs et al., 2001), SARS (Keogh-Brown and Smith, 2008), dengue (Murray et al., 2013) and also Ebola (Baseler et al., 2017). The strength of each disease varies.

The world we live in now is very different from the world a hundred years ago (McKee and Stuckler, 2020). The current socio-economic crisis caused by COVID-19 distinguishes several factors (Nicola et al., 2020; Rasul et al., 2021). Some of the factors include the fact that COVID-19 is a global pandemic and has implications for supply chains, as globalization and advances in technology have made the world much more integrated (McKenzie, 2020). In addition, the world is witnessing advances in science, medicine, and engineering.

\subsection{Counting of macroeconomic indicators GDP}

The gross domestic product represents the total market value of all final goods and services produced in a given time according to the production factors located in the country. GDP does not include intermediate goods but only new products and services to avoid double counting. GDP can be calculated in different ways, first with a value-added approach (or production), which calculates the gross output of various sectors and then deducts intermediate inputs to avoid double counting. Or it can be calculated according to the income approach, which measures the income achieved by many factors of production. Recently, GDP can be determined by an expenditure approach that measures activities such as 
investment and import investment from different industries and imports (Landefeld et al., 2008).

GDP also includes those outputs that are not subject to purchase and sale. These are mainly services of education, public administration, or health care, the volume of which is not negligible. They can also represent more than $10 \%$ of the total GDP. GDP growth is generally understood as the growth of the well-being of the population of a given country. However, economic prosperity cannot be derived only from the development of GDP. Aspects such as quality of life, education, the possibility of self-realization must also be taken into account (Stefko et al., 2019; Stefko et al., 2020).

Another problem is that GDP includes the volume of production and services recorded by the official economy, but there is also a "grey economy" unregistered, which significantly affects the welfare of society. The grey economy is a major source of leakage from public funds such as the state budget, the social fund, and health funds. There is also a black economy, which is made up of criminal activities such as car theft, drug trafficking, and others. In addition, outputs that are difficult to measure because they do not cross the market are not included in GDP, and there are no exact measures to assess the quality of life.

\section{Method}

In the research paper, a time series model was applied using the SPSS tool. Data on GDP growth for individual EU countries as well as the EU as a whole were analysed. Based on the analysis and examination of historical development, it was found that COVID-19 had a significant negative impact on GDP and the economy of individual countries. Based on the forecast, we obtained data on the development of GDP for the EU for the next five years. We also determined the Upper and Lower confidence limits. After analysing several studies and the overall situation, we determined subjectively three scenarios of GDP development in the conditions of COVID-19.

Due to the topicality of the issue and its freshness, we also analysed through the Vos viewer publications concerning COVID-19 and its impact on the global economy. In total, we analysed 1843 research papers and examined which countries are most concerned with this area.

\section{Results}

From the outbreak of COVID-19 at the end of 2019 until August 2021, a total of 1,843 articles were registered in the Web of Science database. Using VOS viewer analysis, we determined the density of publishing activity in the global economy and the pandemic. Figure 1 shows the density for each country. The more pronounced the colour, the higher the red density. The higher the number of articles dealing with COVID-19 and its impact on the global economy means higher the weights of neighbouring objects (in this case countries), and are coloured by red. Conversely, the smaller the number of items around a point and then lower the weights of adjacent items, the closer the colour of the point is to pale blue. In this case, we can see in Figure 1 that most publications on the topic were published in the US, Canada, and in China, India, England. 


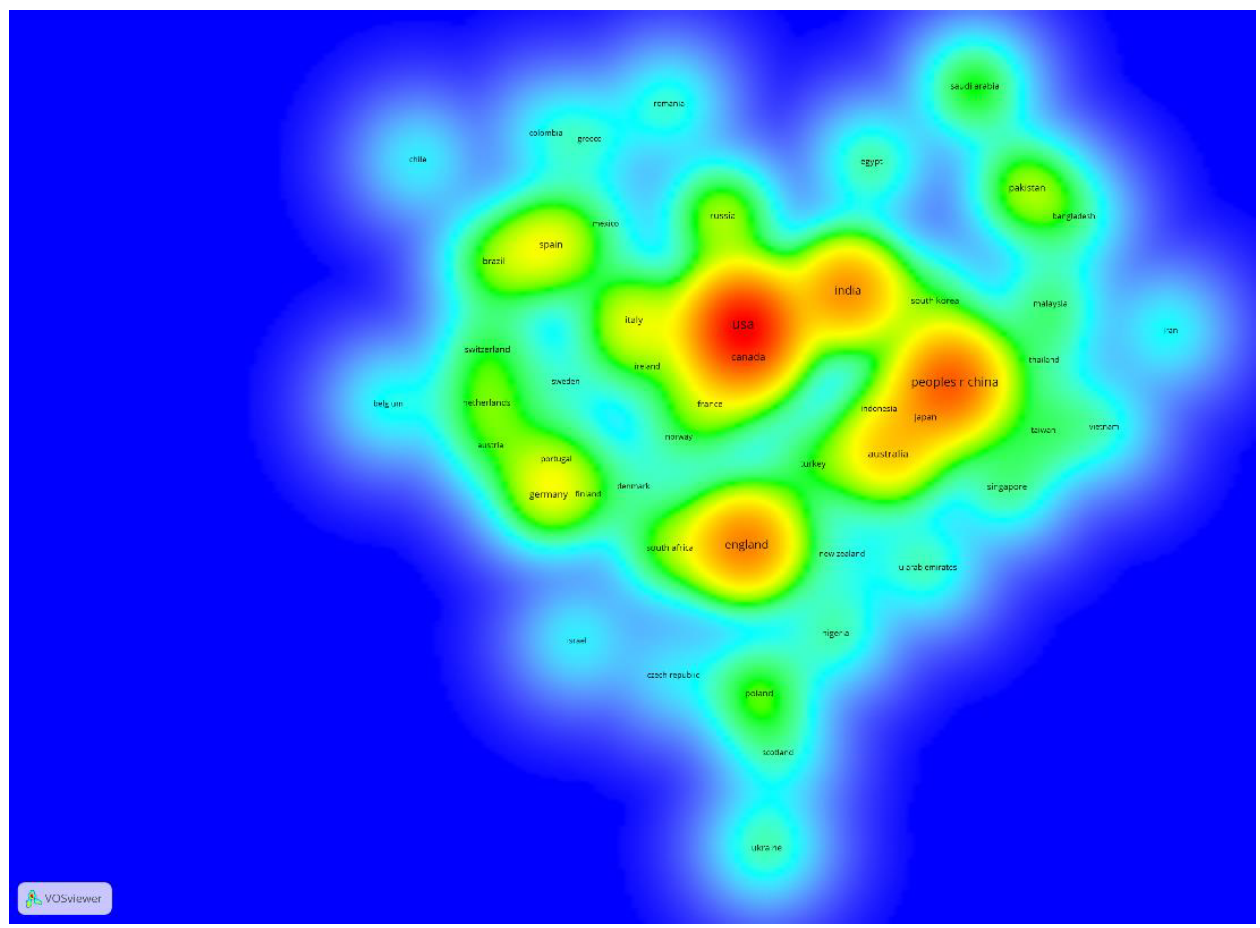

Figure 1. Density of research articles delt by COVID-19 and global economy by countries

Source: own processing

In proposing possible scenarios for the development of GDP for the countries of the European Union, we relied on data for the EU as a whole. The database includes data from 1971 to 2020 . The aim was to predict developments for the next five years and then identify possible scenarios of scenarios that may occur as a result of the development of the COVID19 pandemic. The available data were entered into the SPSS database, and the results of the model are available in Table 1.

Table 1. Model Summary - GDP growth EU

\begin{tabular}{|c|c|c|c|c|c|c|c|c|c|}
\hline \multicolumn{10}{|c|}{ Model Fit } \\
\hline \multirow[b]{2}{*}{ Fit Statistic } & \multirow[b]{2}{*}{ Mean } & \multirow[b]{2}{*}{ Minimum } & \multirow[b]{2}{*}{ Maximum } & \multicolumn{6}{|c|}{ Percentile } \\
\hline & & & & 10 & 25 & 50 & 75 & 90 & 95 \\
\hline \multirow{2}{*}{$\begin{array}{l}\text { Stationary } \\
\text { R-squared } \\
\text { R-squared }\end{array}$} & 0,662 & 0,662 & 0,662 & 0,662 & 0,662 & 0,662 & 0,662 & 0,662 & 0,662 \\
\hline & 0,139 & 0,139 & 0,139 & 0,139 & 0,139 & 0,139 & 0,139 & 0,139 & 0,139 \\
\hline RMSE & 1,922 & 1,922 & 1,922 & 1,922 & 1,922 & 1,922 & 1,922 & 1,922 & 1,922 \\
\hline MAPE & 117,350 & 117,350 & 117,350 & 117,350 & 117,350 & 117,350 & 117,350 & 117,350 & 117,350 \\
\hline MaxAPE & 1971,777 & 1971,777 & 1971,777 & 1971,777 & 1971,777 & 1971,777 & 1971,777 & 1971,777 & 1971,777 \\
\hline MAE & 1,367 & 1,367 & 1,367 & 1,367 & 1,367 & 1,367 & 1,367 & 1,367 & 1,367 \\
\hline MaxAE & 7,036 & 7,036 & 7,036 & 7,036 & 7,036 & 7,036 & 7,036 & 7,036 & 7,036 \\
\hline $\begin{array}{l}\text { Normalized } \\
\text { BIC }\end{array}$ & 1,463 & 1,463 & 1,463 & 1,463 & 1,463 & 1,463 & 1,463 & 1,463 & 1,463 \\
\hline
\end{tabular}

Source: output SPSS 
Based on historical data, we attempted a prediction for the next five years. Based on Table 2 , we see that we have zero outliers and also there are other vital characteristics of the model available such as significance, model fit statistics, and others.

Table 2. Model Statistics

\begin{tabular}{|c|c|c|c|c|c|c|}
\hline \multicolumn{7}{|c|}{ Model Statistics } \\
\hline \multirow[b]{2}{*}{ Model } & \multirow[b]{2}{*}{$\begin{array}{l}\text { Number of } \\
\text { Predictors }\end{array}$} & \multirow{2}{*}{$\begin{array}{c}\text { Model Fit } \\
\text { statistics } \\
\text { Stationary } \\
\text { R-squared }\end{array}$} & \multicolumn{3}{|c|}{ Ljung-Box Q(18) } & $\begin{array}{c}\text { Number of } \\
\text { Outliers }\end{array}$ \\
\hline & & & Statistics & DF & Sig. & \\
\hline $\begin{array}{l}\text { annual \% } \\
\text { growth GDP- } \\
\text { Model } 1\end{array}$ & 0 & 0,662 & 21,056 & 16 & 0,026 & 0 \\
\hline
\end{tabular}

Source: output SPSS

Figure 2 shows the historical development of GDP growth for the EU in red. The prediction for the next five years is blue and based on the figure we can state a slight increase and then a slow decrease.

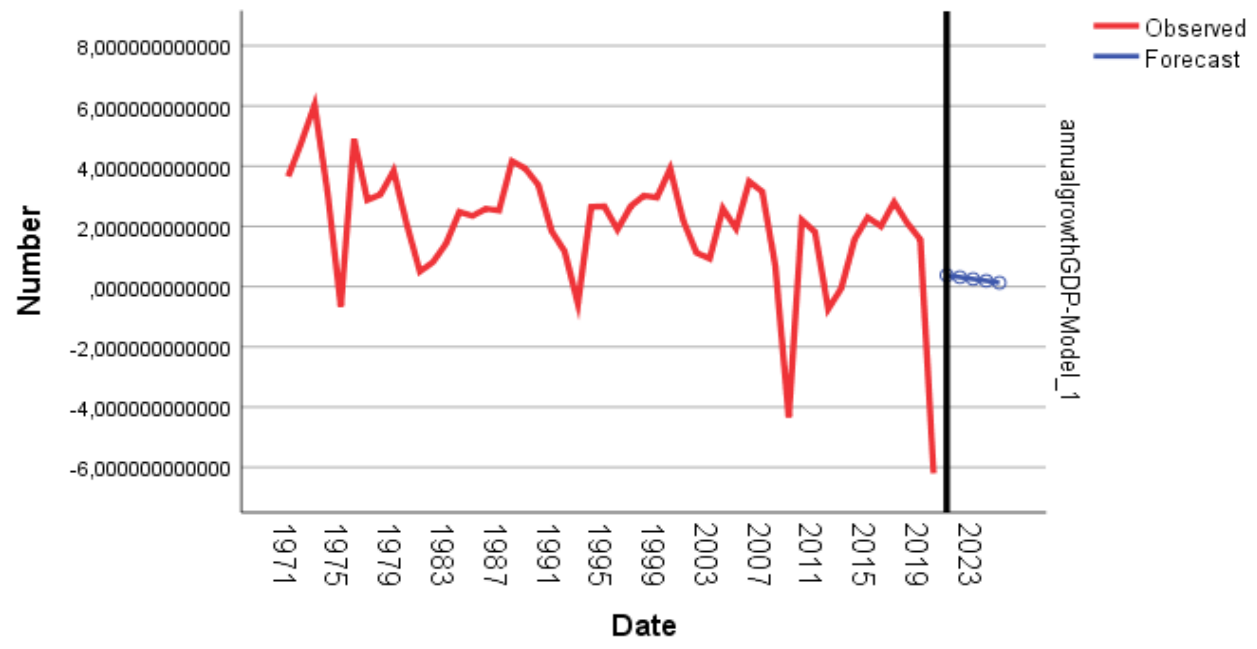

Figure 2. Historical and predict GDP annual\% growth for the EU

Source: output SPSS

\section{Discussion and Conclusions}

After processing the supplied data, the SPSS program generated results for the next five years. The model predicted growth values at a very small level. From the beginning of 2021, the value of annual GDP growth should remain at $0.38 \%$, but then there should be a decline. The table also shows the values for Lower confidence limits (LCL) and Upper confidence limits (UCL). 
Table 3. Scenario forecast

\begin{tabular}{|l|c|c|c|}
\hline \multicolumn{1}{|c|}{ Year } & Predicted & LCL & UCL \\
\hline 2021 & 0,376164 & $-3,48873$ & 4,241059 \\
\hline 2022 & 0,31442 & $-3,5566$ & 4,185442 \\
\hline 2023 & 0,252676 & $-3,62446$ & 4,129817 \\
\hline 2024 & 0,190932 & $-3,69232$ & 4,074185 \\
\hline 2025 & 0,129188 & $-3,76017$ & 4,018545 \\
\hline
\end{tabular}

Source: output SPSS

The first possible scenario could be a shock to the economy and a short-term outage, after which there should be a recovery. Society begins to be vaccinated en masse, the disease weakens and subsides (see e.g. Mitchell et al., 2021; Bailey et al., 2021).

Another possible scenario is that COVID-19 will continue to mutate and have a volatile health impact in most countries. As a result, there will be a loss of performance. The company is trying to live with the virus and is looking for possibilities to deal with the crisis.

The most pessimistic scenario would be for the COVID-19 virus to disrupt global trade. Production, exports, and overall operations would be curtailed until the demand and supply curves shifted inward.

Economic freedom has a significant impact on the annual rate of GDP growth in different models, country samples, and periods under study. There is a positive link between the growth rate and the economic freedom index. The external business environment, earnings management, financial and fiscal freedom, together with freedom of trade, enterprise, and labor, play an essential role in the economic prosperity of many countries. All that remains is to believe that the situation with the COVID-19 virus will improve or that society will learn to accomplish with the virus.

\section{Acknowledgements}

This paper was supported by the Slovak Research and Development Agency under Grant number APVV-17-0546: Variant Comprehensive Model of Earnings Management in Conditions of the Slovak Republic as an Essential Instrument of Market Uncertainty Reduction.

\section{References}

1. Alam, M. M., \& Abdurraheem, I. I. (2021). COVID-19 and the Financial Crisis in the Sports Sector around the World. Sport in Society, 1-14.

2. Acikgoz, O., \& Gunay, A. (2020). The early impact of the Covid-19 pandemic on the global and Turkish economy. Turkish journal of medical sciences, 50(SI-1), 520-526.

3. Bagchi, B., Chatterjee, S., Ghosh, R., \& Dandapat, D. (2020). Impact of COVID-19 on global economy. In Coronavirus Outbreak and the Great Lockdown (pp. 15-26). Springer, Singapore.

4. Bailey, L., Grupac, M., and Sosedova, J. (2021). COVID-19 Vaccine Risk Beliefs, Perceptions, Attitudes, and Intentions. Review of Contemporary Philosophy, 20, 81-92 
5. Baseler, L., Chertow, D. S., Johnson, K. M., Feldmann, H., \& Morens, D. M. (2017). The pathogenesis of Ebola virus disease. Annual Review of Pathology: Mechanisms of Disease, 12, 387-418.

6. Bratu, S. (2020). Threat perceptions of COVID-19 pandemic: News discernment, media exaggeration, and misleading information. Analysis and Metaphysics, (19), 38-44.

7. Carlsson-Szlezak, P., Reeves, M., \& Swartz, P. (2020). What coronavirus could mean for the global economy. Harvard Business Review, 3(10).

8. Fialova, V., \& Vasenska, I. (2020). Implications of the COVID-19 Crisis for the Sharing Economy in Tourism: The Case of Airbnb in the Czech Republic. Ekonomickomanazerske spektrum, 14(2), 78-89.

9. Gibbs, M. J., Armstrong, J. S., \& Gibbs, A. J. (2001). Recombination in the hemagglutinin gene of the 1918" Spanish flu". Science, 293(5536), 1842-1845.

10. Horrox, R. (2013). The black death. Manchester University Press.

11. Keogh-Brown, M. R., \& Smith, R. D. (2008). The economic impact of SARS: how does the reality match the predictions?. Health policy, 88(1), 110-120.

12. Khan, S., Haleem, A., Deshmukh, S. G., \& Javaid, M. (2021). Exploring the impact of COVID-19 pandemic on medical supply chain disruption. Journal of Industrial Integration and Management, 06(02), 235-255.

13. Korzeb, Z., \& Niedziółka, P. (2020). Resistance of commercial banks to the crisis caused by the COVID-19 pandemic: the case of Poland. Equilibrium. Quarterly Journal of Economics and Economic Policy, 15(2), 205-234.

14. Landefeld, J. S., Seskin, E. P., \& Fraumeni, B. M. (2008). Taking the pulse of the economy: Measuring GDP. Journal of Economic Perspectives, 22(2), 193-216.

15. Lambovska, M., Sardinha, B., \& Belas, J. (2021). Impact of Covid-19 Pandemic on the Youth Unemployment in the European Union. Ekonomicko-manazerske spektrum, 15(1), 55-63.

16. Lyons, N., \& Lăzăroiu, G. (2020). Addressing the COVID-19 crisis by harnessing Internet of Things sensors and machine learning algorithms in data-driven smart sustainable cities. Geopolitics, History, and International Relations, 12(2), 65-71.

17. Maital, S., \& Barzani, E. (2020). The global economic impact of COVID-19: A summary of research. Samuel Neaman Institute for National Policy Research, 2020, 1-12.

18. McKee, M., \& Stuckler, D. (2020). If the world fails to protect the economy, COVID19 will damage health not just now but also in the future. Nature Medicine, 26(5), 640642.

19. McKenzie, B. (2020). Beyond COVID-19: supply chain resilience holds key to recovery. Retrieved, 24, 2020.

20. Mikelsone, E., Spilbergs, A., Volkova, T., \& Liela, E. (2020). Idea management system application types in local and global context. Equilibrium. Quarterly Journal of Economics and Economic Policy, 15(1), 151-166.

21. Mitchell, K., Grupac, M., and Zauskova, A. (2021). Ethical Management and Implementation of COVID-19 Immunity Passports and Vaccination Certificates: Lawfulness, Fairness, and Transparency. Linguistic and Philosophical Investigations, $20,45-54$.

22. Murray, N. E. A., Quam, M. B., \& Wilder-Smith, A. (2013). Epidemiology of dengue: past, present and future prospects. Clinical epidemiology, 5, 299. 
23. Nicola, M., Alsafi, Z., Sohrabi, C., Kerwan, A., Al-Jabir, A., Iosifidis, C., ... \& Agha, R. (2020). The socio-economic implications of the coronavirus pandemic (COVID-19): A review. International journal of surgery, 78, 185-193.

24. Ozili, P. K., \& Arun, T. (2020). Spillover of COVID-19: impact on the Global Economy. Available at SSRN 3562570.

25. Reichmuth, B. (2021). The Power of the Plague How the Great Plague Changed the World, 1347-1353. Radiologe, 61(7), 699-699.

26. Rasul, G., Nepal, A. K., Hussain, A., Maharjan, A., Joshi, S., Lama, A., ... \& Sharma, E. (2021). Socio-Economic Implications Of Covid-19 Pandemic In South Asia: Emerging Risks And Growing Challenges. Frontiers in Sociology, 6.

27. Scott, R., Poliak, M., Vrbka, J., \& Nica, E. (2020). COVID-19 response and recovery in smart sustainable city governance and management: Data-driven Internet of Things systems and machine learning-based analytics. Geopolitics, History and International Relations, 12(2), 16-22.

28. Saunders-Hastings, P. R., \& Krewski, D. (2016). Reviewing the history of pandemic influenza: understanding patterns of emergence and transmission. Pathogens, 5(4), 66.

29. Stefko, R., Bacik, R., Fedorko, R., Olearova, M., \& Rigelsky, M. (2019). Analysis of consumer preferences related to the use of digital devices in the e-commerce dimension. Entrepreneurship and Sustainability Issues, 7(1), 25-33.

30. Stefko, R., Fedorko, R., Bacik, R., Rigelsky, M., \& Olearova, M. (2020). Effect of service quality assessment on perception of TOP hotels in terms of sentiment polarity in the Visegrad group countries. Oeconomia Copernicana, 11(4), 721-742.

31. Tan, J. A., Liu, Y., Shen, E., Zhu, W., Wang, W., Li, R., \& Yang, L. (2002). Towards $<<$ the atlas of plague and its environment in the People's Republic of China $>$ : idea, principle and methodology of design and research results. Huan jing ke $x u e=$ Huanjing kexue, 23(3), 1-8.

32. Wagner, D. M., Klunk, J., Harbeck, M., Devault, A., Waglechner, N., Sahl, J. W., ... \& Poinar, H. (2014). Yersinia pestis and the Plague of Justinian 541-543 AD: a genomic analysis. The Lancet infectious diseases, 14(4), 319-326. 